\title{
Media and Construction of Difference: How Media Representations Work to Criminalize, Label, and Induce Border-Restrictions against Young African Female Migrants in Europe
}

\author{
Michael Onyedika Nwalutu1 ${ }^{*}$, Felicia Ihuoma Nwalutu ${ }^{2}$ \\ ${ }^{1}$ Social Justice Education, OISE, University of Toronto, Toronto, Canada \\ ${ }^{2}$ Department of History, University of Toronto, Toronto, Canada \\ Email: ^nwalutu@yahoo.co.uk
}

How to cite this paper: Nwalutu, M. O., \& Nwalutu, F. I. (2019). Media and Construction of Difference: How Media Representations Work to Criminalize, Label, and Induce Border-Restrictions against Young African Female Migrants in Europe. Sociology Mind, 9, 66-85.

https://doi.org/10.4236/sm.2019.91004

Received: October 25, 2018

Accepted: November 24, 2018

Published: November 28, 2018

Copyright $\odot 2019$ by authors and Scientific Research Publishing Inc. This work is licensed under the Creative Commons Attribution International License (CC BY 4.0).

http://creativecommons.org/licenses/by/4.0/

(c) (i) Open Access

\begin{abstract}
The United Nation's Technical Specialist for Adolescents and Youth at the UN Population Fund, Sylvia Wong reveals that young adults currently represent the largest proportion of transnational migrants (Wong, 2009). Migrant youth, and in this context, female African migrants are being subjected to very difficult transit experiences both at transnational borders (Toasije, 2009; Brachet, 2012) and in the receiving societies (Ki-moon, 2009; Solimano, 2010). Our work disturbs existing notion of free movement of individuals across transnational borders to accentuate the effect of Western media representations on Europe-bound female youth migrants from Sub-Saharan Africa. We foreground the pervasive border-restrictions, oppressive treatments, and involuntary deportations experienced by these female migrants in neo-colonial surveillance systems, and tropes of racist securitization masking the interlocking systems of oppression the female migrants have to deal with. The work uses textual analysis to speak to earlier research-report from regimented qualitative field-study conducted in 2013 in the Republic of Malta. It argues that labeling and criminalization of young African female migrants by the European media results in negative public opinions, and subsequently, severe restrictive and oppressive practices against these migrants both at EU borders and in the host societies.
\end{abstract}

\section{Keywords}

Media Representation, Discrimination, Female Migrants, Social Construction, Anti-Racism, African Youth 


\section{Introduction}

Border surveillance and restriction against unwelcome immigrants are fast becoming predictable contradictions that migrants entering industrialized world from developing economies are coming to terms with, and an odd against which they must resist with utmost agency. We insist that series of political and socio-economic activities of the industrialized world have continued to perpetuate disruptions in the developing South (Chua, 2003; Chomsky, 2006; Simms, 2009), causing displacements in the process, and prodding the citizens into forced migration (Sassen, 1988; Baxter, 2008). The forcefully displaced migrants, mainly from the global South are continuously faced with enormous restrictive gatekeeping structures designed to check their entry into receiving societies of the North. Often print and electronic media are deployed strategically to generate negative public opinions to compel and elicit negative government policies against the migrants. The hyped up anti-immigrant media contents is true in most western societies in its most subtle forms. In a contribution to debates on African transnational migration de Haas (2007) incriminates media over-reportage of Europe-bound flow of African irregular migrants and the ongoing anti-immigrant political campaigns in Europe for inducing wrong approach to scholarship on migration between Africa and Europe. In fact Western media amplifications of Africa-Europe migration flow have been blamed for political biases against African immigrants in Europe (Memmi, 2006; Solimano, 2010). Public opinions formed based on such negative reportage often generate impulsive political responses in the form of anti-immigrant campaigns and laws; and at other times, academic researches based on insufficiently sourced data. Thus speculations engendered by media exaggerated reportage of migration of young female Africans into Europe only tend to entrench negative public opinions against the immigrants and encourage less than appropriate researches from academics who share interest on the topic (Berriane \& de Haas, 2012). This approach to understanding the phenomenon of African migration creates and perpetuates reports with illusive notions that Europe is inundated by African migrants.

African migration to Europe is commonly seen as a tidal wave of desperate people fleeing poverty and warfare (sic) at home trying to enter the elusive European el Dorado. Typical “solutions" proposed by politicians include increasing border controls or boosting African "stay-at-home" development. However, such apocalyptic views are based on fundamentally flawed assumption about the (limited) magnitude, historicity, nature and causes of this migration (de Haas, 2008).

On the contrary, emerging literature suggests that the bulk of African migration is intra-continental (Adepoju, 2008a, 2008b; de Haas, 2008; Falola \& Afolabi, 2007, Akanle, 2013). Nonetheless, mounting evidences show that many young Africans, and specifically female youth are continually on the move to enter the European mainland (Brachet, 2012; Adepoju, 2008b; Falola \& Afolabi, 
2007; Akanle, 2013). This waork attempts to advance beyond the Push and Pull discursive paradigm of transnational migration and highlight yet the entrapment that EU border restriction has come to represent to the struggles of African female youth migrants. After the 911 terrorists attacks in the United States, Western transnational borders transformed to politicized spaces for migrants' restriction, negotiation, and resistance. It thus becomes reasonable to assert that this gate-keeping and supra-surveillance processes are grounded on biases constructed around migrants' gender, nationality, ethnicity, race, religion, and cultural affiliations (Sharma, 2005; Nyers, 2010). The work of de Haas's (2007) does not seem to deny the flow of immigrants from Africa to Europe, we believe, he only reasoned it might not have been at the rate such phenomenon is represented by western media. The current trend of media influence on attitudes toward young female African migrants in Europe demands every investigation and research given the oppressive backlash such reportage holds for these migrants in the host societies. The salient questions that will guide the thrust of this work are: why would female Sub-Sahara African youth migrants continue to be victims of host societies' misjudgments and violation of international codes of practice? How might the efforts of sending and receiving societies be coordinated to evolve youth-sensitive and female-migrant friendly interventions?

\section{Review of Literature}

The media in most industrialized countries can, and have set frameworks for debates on natural and man-made disasters, social, economic and political affairs, and particularly issues of demographic displacement and migration (Siebert, Peterson, \& Schramm, 1963; de Haas, 2006; 2008). Sometimes information is deliberately blown out of proportion to weep up sentiment, depending on the political leaning of the media stakeholders. At other times, similar information from developing countries are underreported or shrewdly misrepresented. For example in 2016, a Irfan Siddiqui of the Pakistani community in the Greater Toronto Area, GTA wondered aloud on the $29^{\text {th }}$ of March issue of the Metro Toronto Newspapers why a little was published by the Western media on the terrorists bombing in Pakistan, which claimed 70 lives, while the previous incident in Belgium, which left about 34 people dead raised all the dust in every conceivable media in Western societies. He regretted, "I'm not calling it racist, but you can see the difference", said Irfan Siddiqui, "It's as if the value of life in a third world country is not the same as that of the first world country" (Ngabo, 2016). The dialectics almost always favor industrialized world. In this vein, media casts in industrialized world also elicit negative opinions and attitudes towards irregular migrants, majority of who are refugees and asylum seekers from the developing world; and Europe-bound female African migrant youth are not exceptions. We would continue by arguing that refugees and migrants in Europe have indeed been framed negatively by the media as problems, rather than a benefit to host societies (de Haas, 2008; Abuzayd, 2016). Of course this posture has been the basis for the push and pull narrative that blames immigrants and 
sending nations for the inherent problems of migration. We are not however arguing that western media outputs do not occasionally have positive influence on public attitudes and policy, but that has not been the case with sub-Saharan Africa female migrants. In a UN mandated study on Syrian refugee crisis Abuzayd, (2016) content-analyzed EU media with respect to pattern of domestic and political sourcing of media outputs. In order to accentuate variations between EU countries on immigration, her work indicates that domestic politicians have consistently been the key most accessed source category in news accounts. Relevant to this chapter is the report that features patterns of political sourcing, which indicates that governing parties or coalitions dominate political sourcing, and in most cases the key challengers were from the anti-immigration right-wing:

In the UK $68.6 \%$ of political sourcing came from the coalition government whilst the main voice explicitly opposing government policy came from UKIP (9.3\%). In Spain, where political sourcing was unusually low, the People Party was dominant with $78.9 \%$ of source appearances. In Italy, Matteo Renzi's coalition secured $62.7 \%$ of political source appearances with the main opposition coming from the anti-immigrant right (Northern League and Forza Italian 19.7\%). In Sweden, the 2010-2014 coalition featured in $51.3 \%$ of political source appearances with the main opposition coming from the far right Swedish Democrats (20.6\%). Germany was unique in that the main opposition to the Merkel's grand coalition (79.6\%) came from the left in shape of the pro-immigrant Left/Greens (18.0\%). 3. The great bulk of articles featured some information on the country of origin of refugee and migrants, though this varied by country. Whilst almost all articles in Spain (89.1\%), the UK (87.4\%) and Germany (86.5\%) included this background, in Sweden (72.5\%) and Italy (69.6\%) the proportion was lower (Abuzayd, 2016).

Abuzayd's work depicts variations in how the press in different countries of industrialized West report on asylum and immigration, with Sweden leading as having the most positive press output towards refugees and asylum migrants. "Despite significant representation for the far-right Swedish Democrats and a low proportion of NGO sources, it featured a preponderance of humanitarian themes, few examples where refugees and migrants were framed as a threat, and strong advocacy of a more liberal and humane EU asylum and immigration policy" (Abuzayd, 2016). This contrasts sharply with similar coverage in the United Kingdom, which was mostly negative:

Despite the presence of newspapers such as the Guardian and Daily Mirror, both of which were sympathetic to refugees, the right-wing press in the United Kingdom expressed a hostility towards refugees and migrants which was unique. Whilst newspapers in all countries featured anti-refugee and anti-migrant perspectives, what distinguished the right of centre press in the UK was the degree to which that section of the press campaigned ag- 
gressively against refugees and migrants. This could be seen in the preponderance of negative frames and the editorialising in favour of Fortress Europe approaches.

Irregular migrants and international border securitization are becoming predictable paradoxes. Lowry and Nyers (2003) explore the global movements of refugees and migrant rights. Their work expresses concern on the impact of the heightened securitization of borders and intensification of selective surveillance on the cultures of political asylum (of countries like Canada for instance), as it affects international freedom of movement. The key idea pervading their work remains the identification of the verity and source of migrants' political agency. Lowry and Nyers' work as exposé on critical border interactions between migrants and receiving nations, shows different measures adopted to refuse immigrants entry when state and media prey on their citizens' gullibility by framing migrants as murderers (Australia), criminals, and fanatical terrorists (Europe). Similarly, Europe-bound female African youth migrants are portrayed in media as either victims of human trafficking syndicates or lazy louts arriving to take undue advantage of EU welfare system. Despite working hard to support themselves, scarcely was this category of migrants depicted as making any form of economic contributions to their host societies (Pisani, 2012). The work of Lowry and Nyers (2003) also reflects on struggles of activists for migrant rights, and the migrant peoples' resistance. It draws extensively from Mai Kaneko's and Helena Schwenken's contributions on the active contestation of oppressive and restrictive immigrant and refugee policies in Afghanistan, Canada, the European Union, Australia, and Japan. It is as Sassen (1988) suggested earlier, a ploy to tag immigrants as problem to the receiving nations (see also: Sharma, 2005, Li, 2003). It is therefore the view of this chapter that the lopsided power relationship in international boundary policing and surveillance is a renewed ploy of Western colonial overlords to control the flow and trend of transnational migration by tightening their hegemonic grips on the rest of the world.

In an attempt to expose the challenges posed by ambiguities and insecurities resulting from the erosion of the traditional components of modernity to both the sovereign subject and sovereign nation state as it affects transnational borders and regulation of national border-crossing migrant, Kapur (2005) examines how the current extraordinary movement of people across international borders exposes "the porosity of borders, the transnational reality of subaltern existence, and the contingent foundation of international law" (p.137), by interrogating how, on one hand, encounters with the constitutive "Others", or the transnational migrant subject disrupts and disturbs universalists' notion of international law, and on the other, the modernists' perspective on international law that attempts to counter, curtail, restrict and resist the cross-border migrants. Kapur's work is relevant to this chapter in helping to expose the power imbalance in the management of international border and movement of goods and persons across these borders. It is especially disconcerting that the whole idea of universality of 
cross-border movement as it relates to the international migrant subjects receives its definition, interpretation and meaning from the West. If therefore the legitimacy in international law as it affects cross-border migration is validated, challenged or altered based on the individual's position about modernist argument of human progress, or level of alignment with the dominant social group, it leaves much to be desired. Deaux (2006) reviewed how the patterns of US immigration influence domestic policies to explain how combination of three socio-political factors-policies, demography and social representation-have continued to shape the trends and flow of contemporary transnational migration and immigrant experiences. In his view, United States government's policies on immigration and the demographic realities of the country are two elements interlocking to produce specific flow into the country and immigrants' experiences in the United States. The third factor, social representation is not as tangible as demographic data, yet is, according to Deaux, even more critical in shaping immigrants' experiential realities in their host society. Social representation as the articulation of "attitudes and images that a community holds about immigration-in general, as well as about particular groups of immigrants-is a critical member of the triad" (p.13). This becomes the case considering that often policies are influenced by the subjective views of a country's authority rather than on objective derivatives of data analysis. In the same vain the process of social representation and interpretation of events, ideas and processes also influence a people's political actions. We argue however that Deaux subsumed the experiences of transnational migrant youth in his analysis of the US national Immigration Reform control of 1986, for we are learning nothing special about how this restriction of immigrant flow influenced youth migrants' experiences in the country. Also his work did not show the voices and opinions that were silenced even among the US citizenry, for it was certainly the voices and opinions of the dominant European Americans that are reified, valorized, validated, and legitimized as the voice of America. In other words it is the opinion of this segment of Americans that determines who becomes legal, or illegal and who must be repatriated or retained to become American citizen-not the opinions of the Indigenous peoples of America, African Americans, Latin Americans and other immigrant settlers-whose narratives must not be swept under the carpet if the history of United States must be viewed through a holistic spectacle. As stressed somewhere (see Nwalutu, 2015), the efforts on border securitization among industrialized nations are apparently going far beyond the spheres of the nation state, to imagined territories. Guild (2005); in her critical question, ... who is entitled to move? (p. 14), notes that industrialized Western nations created globalization to position economy-driven mobility above the authority of the nation state in which multinational corporations secure passage across the barriers of transnational borders using their economic powers. Definitely citizenship privileges would be seen here to favor those of industrialized world whose passports of travel defy all manner of border restrictions. The rhetoric questions emerging 
would be: why would notions of Difference pervade the space of border adjudication and securitization? Why are certain gradients of skin-color constructed as transnationally border-proof and others are not, and how might we begin to deconstruct border politics that essentialize and reify dominant bodies at the spaces of politicized skin-pigmentation?

\section{Feminist Post-Structuralism and Transnational Border Securitization}

We would borrow critical lenses from Browne (2007)'s work to highlight the relevance of major concepts of feminist post-structuralism in the processes of border securitization and migrants' subjectification. Browne advances her view from the Canadian permanent residence card system PRC, which as a "signifier" of authentic subject and citizenship is both positivist in view and essentialist in practice, of which post-structuralism is opposed (Browne, 2007: p. 34; Belsey, 2002: p. 15). Browne used the case of Brandon Mayfield (p.118) to argue against the assumption of infallible objectivist biometric technologies. This implies that the state's assumption that the PRC and surveillance technologies encode infallible "truth" about its subjects through which to identify and differentiate people is brought to question, for post-structural theorizing encourages deep suspicion of universal claims of singular "truth" (Rosenberg, 2004: p. 36). While Browne's work on racialization and border control (Browne, 2007: p. 43) is outstanding in portraying the power dynamics of the Canadian state in relation to its constituted subjects, foreigners applying for PRC, we are left worried that her assertive writing style forecloses some discourses that may trigger questions on her assumptions. It feels more like reading a meta-narrative of Canadian PRC intervention in which the states of Canada and US, and their private/public allied corporations without restraint; and with preconceived notions of who becomes the "trusted traveler" and/or the illegal migrants, constructed the positive and negative spaces into which each of these categories must fit. The reader might ask if the migrant subjects themselves in any way contribute in the process of subjectification they face at Canadian border, for instance the government of Canada allows entry to refugees. "A convention refugee and person in need of protection are people who are unable, or by reason of their fear, unwilling to be protected by their country of origin" (Immigration and Refugee Board of Canada, Interpreters Training Manual, 2010: p. 7). It implies a power relations in which the immigrant is neither hapless nor helpless as the author depicts.

Davies (2006)'s elaboration on Butler's subject becomes useful. The subject possess agency, although radically conditioned agency in which they can critically review their options and possibilities and in which they can "subvert and eclipse the powers that act on them and which they enact" (p.426). Also Davies highlight on Foucault's theoretical frameworks on subjectification becomes relevant - the paradoxical conditions through which the accomplishment of subject-hood is made possible - for the authority of the state does not act externally on the subjects compelling utter compliance, but in Foucault's view, power 
formed the subject as well, as "providing the very condition of its existence and the trajectory of its desire" (p. 426; see also Belsey, 2002: p. 54). we espouse Rosenberg (2004) in questioning Browne's ideas about knowledge in the state control of PRC as "innocent" or outside of the workings of power' (p.41), obviously because her arguments worded as advocacy tool which is apparently in order, portrays the author not as a subject also but arbiter, but then one may ask where does she locate herself in the whole saga?

The author's use of textual features: collocation patterns and nominalization in examining words contained in documents of parliamentary processes in order to interrogate border control and high-tech securitization measures (p.100) is commendable, yet we would insist it is on one hand subjective (aimed at justifying her position, after all, she cannot, according to post-structuralism) claim to possess the "only" interpretation ascribable to the meanings in those texts (see Belsey, 2002: pp. 21, 71); and at the other, abstracted from the individual migrants constructed as subjects against whom she purports that protectionist policies and the militarized borders were structured. Browne's decision to analyze few print media reports on the experiences of PRC subjects instead of using survey and/or ethnographic interview (p.23, 162ff) is what we found to be a bit of methodological, specifically instrument problem. By so doing she invisibilizes the "subjects" and therefore not only trivializes the illegal immigrants' identities, but reproduces an imbalance in power structure (relations) between herself, the author and even the categories of immigrant subjects her work is set to advocate for. Objectivity, Sharon Rosenburg argues, is only assumed from the perspective of the privileged (p.41). The questions we continue to ask here are: who own these newspapers and whose interests and policies are those print media's news coverage on experiences of the "trusted" travelers and "risky" aliens reflecting? The answer is of course, the neoliberal state and capitalist public. Could these media biased by total absence of proximity to its subjects have been a reliable source of immigrant experiences as the author assumed? If not, what then is the justification for the choice of secondary source instead of primary source that interview could have provided? Central to our argument is the view that information provided in the newspapers could have been filtered from the perspectives of the vested interest and lenses of Canadian and American states and their private allies, and therefore convey their preconceived opinions (biased by race, nationality, gender and status) that equips them with binary oppositions expression for producing differentiated and identifiable state subjects (p.122) using the machinery of surveillance, identification, and control that Canadian PRC signifies.

Browne successfully exemplified the complex of identity commodification as strategized through surveillance, militarism and commercialization of risk management which we think finds relevance in the post-structural prescriptions of neoliberal ideologies of autonomous self, bureaucratization, responsibilisation and market oriented strategizing (p. 123; Davies, 2006: p. 436). However in this 
work, individual subjects or travelers are constructed as passive recipients and victims of state's control apparatuses in a neo-liberal regime. Judith Butler asserts that subjection is the subordination brought on itself by the subject which is a precondition for agency (cited in Davies, 2006: p. 429). Although we will look at this subjects through Foucault lenses in which subjects are seen as desirous of freedom, this means submitting to subject-hood or "becomes a good disciplinary subject"; we also recognize that as much as power imbalance always produces resistance, the surveillance, disciplinary and border control technologies must be and has been resisted by the "illegitimate non-trusted travelers" too, for in Foucault's view, even the disciplinary subject is capable of resistance (Davies, 2006: p. 426; Belsey, 2002: p. 71). We will further reason that the PRC and events of its assignment, while part of the bureaucratic governance of "permanent residents" as a population, also produce the monitored and controlled Canadian citizen as an effect because once at the border, the citizens would pass through the same border screening processes as do the immigrants until the system certified them to be "bona fide citizens". As Scott (1991) notes "Being a subject means being subjected to definite conditions of existence, conditions of endowment of agents and conditions of exercise" (p.793). This brings us to the notion of responsibilisation which pervades the era of globalization. Here individual subjects are required by the state to be only responsible to self and shed responsibility for others, but actively participate in surveillance and control (Davies, 2006: p. 436). And as Foucauldian subject becomes a "good disciplinary subject", it is capable of resistance and by engaging in such, it emerges in freedom (Brown, 1993: p. 397).

Browne's work argues that September 11, 2001 terrorist attack on US not only spurred the intensification of joint-states surveillance and control of mobility across Canada-USA geopolitical borders, but stimulated the use of surveillance technologies. we will add that mobility surveillance and state control of territorial borders is as old as the creation of nation-state in the Mercantilist period, specifically, during the 1648 Westphalia treaty marking the end of The Thirty Years' War. Surveillance and control of transnational mobility has been a major concern of the international community prior to, during, and after the two World Wars 1914-1918; and 1939-1945 (Moses, 2006: p. 42). While the earlier passports and other documents were actually used to protect foreign travelers in England, Magna Carta granted merchants "unhindered travel in accordance with ancient and lawful customs" but the state (sovereign) "retained the right to expel or exclude specific groups of aliens" (Moses, 2006: p. 40; Kapur, 2005: pp. 141-142), an experience similar to what currently obtains at the Canada-US border.

One issue we think Browne should have elaborated on stems from her acknowledgement of Roxana Ng's contributions to her academic success in which she hinted how she was inspired to think of "how gender operates at the site of the border" (p.iv). Although she proposed to explore how penalties and waivers were assigned at the Canada border control based on specific categorization that 
included gender (p. 24) this to a large extent is left unaddressed. However, in the other segments of her work, the major emphasis is on the use of female image and juxtaposition of foreign names on prototype PRC (pp. 178; 187) as a code to depict "risky" countries whose nationals would be subjected to border interrogations. We anticipated that the author could have investigated how gender is constructed through the prisms of binary oppositions of male and female, for according to Rosenberg (2004) discourses of femininities and masculinities in particular produce and are produced through a wide variety of effects of embodiment, constituting specifically gendered subjects into "woman" and "man"” (p.44) Feminist post-structuralism according to Sharon Rosenburg, sees what we do, not what we are (our physical appearance as captioned in PRC) as determinant of sex. This speaks to Butler (1999) performative discourse in which constant and consistent doing of gender is a requirement. Browne's work should have raised a major confluence of gender constructions and practice at which PRC's notion of gender could be interrogated, contested, disrupted, and possibly modified to accommodate other gender categories not represented in the existing template of PRC.

\section{Method of Data Collection and Analysis}

Data for the preliminary study upon which this work is based was collected during a three-month qualitative field study conducted in the Republic of Malta, EU from August to October, 2013. The chapter textual-analyzes a segment of the research that focused on the lived experiences of Nigerian youth migrants to Europe. Interpretative phenomenological Analysis IPA was employed in the initial data analysis. Application of interpretative phenomenological analysis in the original research provided basis for the work to explore in great depth how the research participants (Nigerian youth migrants in Europe) made sense of their transnational migration experiences. Understanding the epistemic realities of African youth migrants to Europe was the central goal of that study, and the merit of IPA as analytical tool is the light it cast on the broader context. It might justifiably be argued that in IPA, breadth is literarily sacrificed for depth (Smith \& Osborn, 2007). The main currency for IPA study according to Smith and Osborn is to explore "the meanings particular experiences, events, or states hold for participants" (p. 53). The rationale for adopting interpretative phenomenologi$\mathrm{cal}$ analysis in this chapter therefore is that IPA elicits the meanings individuals involved attribute to events and experiences of life as it occur in the narratives with respect to the concept of analysis, which in this case is: the unrelenting flow of African female youth migrants into Europe and the roles of EU media in construction of restrictive gatekeeping structures through labeling, and criminalization to influence public opinion and policies. In the chapter therefore we ground our analysis on anti-racist theory in order to trouble existing border restriction practices that have perpetuated Difference or Otherness around female African migrants in Europe. 


\section{Analysis}

\subsection{Selective Migrants' Restriction at the EU Borders against Young African Female Migrants}

Relating the discourses of anti-racism to the phenomenon of African youth's experiences at the European borders, the realities of skewed power relationship begins to emerge. The systems of border securitization and surveillance are designed to intercept and detain signifiers of racialized bodies or their representation. The taking up of such worded symbolisms as victims of traffickers, Illegal migrants, Clandestine and Boat-people are racist coinages of representation and markers of social difference at the borders of European Union. The disturbing reality of representation of difference is the positioning of the racialized indi$\operatorname{vidual}(\mathrm{s})$ at the margins of social echelon. Spaces such as the transnational borders have the tendency to reproduce hegemony, dominance and privilege because such spaces also come with particular histories and readings. Therefore the experiences of the racialized bodies of female African youth in European borders cannot be fully grasped in discourses of splits binaries of regular or irregular, legal and illegal migrants, because we are not unaware of the maxim that occupying certain spaces comes with meanings and politics. It is paradoxical that European youth traveling to Africa might not face similar harassment, criminalization, restrictions detention and deportation female African youth migrants suffer at the borders of Europe nor do goods daily taken to the industrialized world from African continent. Whiteness is in essence, a system and is also a property. The dominant media under-valorizes Othered bodies at the spaces of skin-color politicization while whiteness is reified. There is therefore a politicization of biological pigmentation at the spaces of border representation, within which context; whiteness becomes a pigmentary passport of privilege. The racial positioning of whiteness at international borders implies that European youth travelers might not be facing similar border restriction and untoward infantalization and deportations African female youth face in Europe. We must, as a way of averting romanticism on transnational migration experiences of African youth also insist that Sub-Saharan African female youth migrants are complicit to their repressive migration experiences and untoward treatment at the entry-ports of Europe.

\subsection{Media Misrepresentation, Criminalization, Public Opinions and Miseries of African Female Youth Migrants in Malta}

The removal of internal borders among member states of the European Union intersects with the declaration of the free movement of persons within the Union to create a more ominous tension symbolized by the increased restriction of borders against non-European nationals. Border restriction against non-EU nationals also implies a rise in media misrepresentation and as a result, criminalization of African migrants and others who are perceived as irregular, clandestine, or undocumented migrants (de Haas, 2008). Against this backdrop the European Union Commissioner for Human Rights decried the untoward practices 
of migrant criminalization and repression as unethical. The commissioner further noted that the practice is counter-productive as a measure against irregular immigration (EU Commissioner for Human Rights, 2008). Female African youth migrants' criminalization is a violation of existing international laws and standards and it often mounts unnecessary, indirect pressure on migrants to resort to more perilous alternative modes of reaching their intended destinations (de Haas, 2006; Sassen, 2003). Our observation is that instead of reducing irregular migration, criminalization and restrictions at EU borders produces rather a conflicting outcome as the influx of migrants is increasing and activities of human smuggling syndicates are also on the rise (Castles \& Miller, 2009; Pisani, 2011). Understanding how policies enacted by the EU immigration authorities jeopardize female African youth migrants' chances of survival would enable a critical unraveling of how the actions or inactions of privileged individuals have continued to uphold the subordination of the migrant other. Female African youth migrants in Malta have a higher possibility of being deported back to their countries of origin after the mandatory one year, six month detention. The earlier study reveals that their claims for asylum and refugee status compared with those of their male counterparts are often rigorously challenged and denied (See Pisani, 2012; Nwalutu, 2016). As Ife, (for privacy and security reasons we use pseudonyms of respondents in this work) a male interviewee who arrived in one of the migrant boats, elucidated: "The Maltese government deported them back to Nigeria. Not a single woman remained in my boat. They deported all to Nigeria (Nwalutu, 2016)." One major reason for the deportation extracted from the experiences of female African youth migrants was their vulnerability in the Maltese labor market. For as Pisani (2011b) argues "the situation is further aggravated by the present financial crisis, and yet, despite their irregular status, migrants continue to meet the labor market's demand for unskilled labor" (p. 25). However, the young female migrants might not risk the tedious work at the construction sites and farms, where their male counterparts are assigned to work. The Stockholm Programme, which laid out the critical priorities for the EU policies on immigration, has apparently been tacit about the rights of irregular migrants who cannot safely return to their states of origin. This air of silence is ambiguous because it also violates the international declarations on the rights and freedoms of refugees and asylum seekers. It fails to address issues of the exploitation of these individuals. For female African youth migrants, the pressure to resist repatriation coupled with the denial of all statuses means they cannot leave the Island of Malta for mainland Europe. Therefore, as a measure of resistance to deportation and consistent with Schwenken, (2003), some of the female migrants defy the consequences to feign mental and psychological conditions, which are made obvious in the voice of Uder, one of the migrant participants in the focus group meetings:

Yes, I believe as a human being spending 12 months in-we are talking about 365 days-in one place, the Maltese government should at least con- 
sider giving us status documents. Until now we have not received a court document, travelling document, or temporary-stay document; we have nothing. I just have what they call a police report, meaning police knows that I am in Malta; which means they may decide at any moment to deport me back to my country. I am not scared of being deported back to Nigeria; I am not afraid of it. But it shouldn't come after I spent one year six months in detention. I had a friend, who was my boat-mate, because she doesn't want to be deported back to Nigeria, she feigned madness while she was not in any actual sense crazy. Instead of deporting her, the authorities took [her and] all of them in this category to Mount Camel. They took them to the psychiatric hospital; they started treating them as mad people; and after they received the treatments and went through the interventions they became mad indeed (Nwalutu, 2016).

Alo, another participant in one of the focus group meetings conducted during data gathering in Malta in 2013 corroborated Uder's views by insisting that:

The Maltese Psychiatrists would tell them: "Listen, if you are not sick, if you are OK, don't allow me to inject you or [have you] take all those drugs (medications)." But they would insist that they were mentally challenged. Today, if you go to the Open Detention Centre at Marsa you will see that many of them are crazy. They are now helplessly mentally deranged. They go to that extent because when you hear of Europe you think it is paradise; you think it is where your destiny is. They want to stay in Europe and they don't know what's called Europe; so they decide to feign that they are insane. This has happened to men and women but disproportionately women. They are in the psychiatric hospital spending six, seven, eight months there before they are released. Remember, you will not go into the psychiatric hospital without being treated for mental health, and that is the cost of their resistance to deportation threats from Maltese authorities (Nwalutu, 2016).

Another female interviewee, Devon, reflected on the suffering and risks they had to undergo to arrive in Europe and decries the callous treatment from the Maltese authorities. She recounted:

After suffering from the Sahara Desert, passing through the Libyan war and crossing the deadly Mediterranean Sea, even surviving its waves and turbulence, we managed to arrive safely. Do you realize that some of us even died? And some were so sick that after they arrived that they were air-lifted to hospital in ambulances; and after landing in this country they sent us to detention for a year and six months. It is not fair. That's why many people when they were released from detention started going crazy. They became mad and started misbehaving, and they started acting abnormal. It was unfair because we passed through a lot of stress; even staying in real prison for one month would be by far much better compared to the stress we passed 
through when we were coming to this country. But the government authorities added to this stress by subjecting us to another round of one year and six months in the detention facility. It was awful. Even the food they gave us was in the most unfriendly manner. They would throw spaghetti at us like animals. And they would serve us spaghetti in the morning, maybe with one egg, spaghetti in the afternoon, and spaghetti in the night; every day we continued to eat the same food. And even when we had people outside who wanted to give us things, the inhuman detention policies and conditions did not permit that. Even when people provided clothes for us, they would refuse to give them to us, [even though] we were not prisoners. The Maltese authorities reacted quickly by sending these young women to the nation's top psychiatric hospital for treatment and many have lapsed into full blown mental illnesses (Nwalutu, 2016).

Another experiential reality of the female African youth migrants in Malta touches the critical nerve center of their reproductive rights. Authorities at the various immigrant detention facilities in Malta are prone to offering the youth a shrewd alternative to undermine the long, unhealthy 18 -month detention. The offer for male and female youth is to couple and achieve pregnancy. When the female detainee becomes pregnant, the couples are released to the better environments of the Open Detention Facilities. Some of the interviewees who yielded to these misconstrued "opportunities" never had it easy. With a monthly allowance of one hundred and thirty Euros $(€ 130.00)$ from which each family was expected to pay one Euro per day for their lodging, there was little left for the couple to take care of their needs or to provide the bare necessities of life for their newborn or unborn babies (Nwalutu, 2016). The distressing condition of youth migrants who yielded to the pressure of "coupling" in the detention as a way of avoiding the protracted and depressing one year six month detention is epitomized in this interviewee's narrative:

While they promised to give us one hundred and thirty Euros every month, what does one hundred and thirty Euros solve for a family? It's not enough to eat for 10 days or even till half of the month for 15 days. What does $€ 130.00$ do for you and your family? It means nothing! Also, if you have to work, you have to be paying them for the government camp. For the government camp that they provided where people should be staying, you have to pay again. If you have to go and work, they will drive you out. I now have a wife, and a baby, I have no job. They will drive you out of the camp (Nwalutu, 2016).

In all, the African young female migrant's image is the most brutalized by the EU's oppressive immigration policies and practices that in the first instance deny her rights as a world citizen. Not only were they cajoled into untimely and unnecessary familial life - to become pregnant through' coupling' with fellow male detainees-as alternative for longer detention time, they risk health complica- 
tions being pregnant in woefully unhealthy detention conditions. After delivery, their babies also become enmeshed in the intractable puzzle of statelessness.

\subsection{An Excuse to Offend: Maltese Authorities' Racist Gaze at African Female Youth Migrants' Sexual Bodies}

Of disturbing importance to our theme is the unfounded assumption that all the female youth migrants from Sub-Saharan Africa must have at younger ages undergone female genital mutilation (FGM). The neo-colonial voyeuristic gaze at African females' reproductive bodies in this situation assumes another dimension. While we in no way intend to deny the existence of FGM as a ritualistic practice in some African societies, this article aims rather to interrogate and deconstruct the media-hyped psycho-politics manifestation of neo-colonial power imbalance inherent in the systems that construct certain socio-cultural practices in developing economies as negative, primitive, and unhealthy while rationalizing similar practices in developed nations. FGM should be viewed in the same light as the vicious system of cultural suppression in the industrialized world that would simultaneously uphold or at best remain silent about practices similar to what was denounced in developing societies. Otherwise, what explanations can neo-liberal capitalist organizations such as the World Health Organization (WHO) give to pressure the governments of some African nations into promulgating domestic laws and complying with international declarations against FGM? At the same time, WHO and the like NGOs are turning a blind eye on the surging trend of essentialization, universalization, commodification, and commercialization of female and male sexual organ mutilations and surgeries (leading men to become women and women to become men) that is currently taking place in Western societies in the glorified name of vagina (labia) tightening and reduction surgery or transition of gender, etc. These lopsided transnational play are better located in the broader framework of unequal power dynamics between the players at the stages of global politics. In his Black Skin, White Mask, Franz Fanon (1952), uses a juxtaposition of White and Black races within the context of colonization to unveil the problems of Black identity in the milieu of Western racist and colonial repressions. This brings to question again first the assumption and therefore practice by Maltese health officials of reconstructing Sub-Saharan female migrants' vaginas after child-delivery in their hospitals without first obtaining any kind of informed consent from the patients. It leaves us with the tasteless question-could this have been informed by another sexual and fecundity issue, in this case, the anxiety of the dominant bodies? For according to Pisani (2011):

Initially unsure as to how to address the particular post/antenatal needs of female asylum seekers, the Maltese medical profession has seen fit to, following childbirth, conduct reconstructive surgery on the vaginas of these women who have undergone FGM. The women themselves were not informed of this decision and the corrective procedure was conducted without their informed consent. (p. 69) 
As an activist, Pisani might have been obsessed with the violations of the privacy rights of the young female African migrants in question (and) the obnoxious practice in her country, Malta; but overlooked the covert possibility that the media-induced fear and anxiety over migrant bodies' fecundity could have spurred another sterilization exercise that was perpetuated on the subjugated bodies without recourse to the ethical requirements of personal consent. A similar incident was reported about Ethiopian female migrants in Israel (see Nesher, 2015; Kneli, 2013). In Fanon's (1952) work, Blackness was projected by the West as a symbol for all negative values or instincts, so that the sexuality of the Black man symbolized a troubling sexual deviation in the White man's imagination. This subconscious state of mind devolved to the projection of European sexual anxieties and guilt onto the superscription of the Blackman so that the potency of the Blackman created a sense of inadequacies and insecurity in the Whiteman's psyche whereby he (the White man) was jealous about and unarguably craved the potency of the Blackman. It is most likely therefore that the fears and anxieties in the haunted psyche of EU watchdogs are finding expression in its media as a way of influencing public opinion and policies against African migrants. Since the $21^{\text {st }}$ migration is not about what Africa does but a global phenomenon understanding and attending to why people move might prove more productive than edging out the alien as is evidence in most industrialized nations today. Phillips (2014) reasons.

Assuming that all people have the same reason for leaving their homes and getting onto boats, that all people rescued at sea are migrants and that there is a one size fits all policy response misrecognises the heterogeneity of this group. Such heterogeneity includes country of origin, gender, age, (race and ability, addition, mine) and family make up including pre-existing links to Europe.

Besides subjectification and feminization of a segment of migrants involved in the African-Europe migration and criminalization of the migrants, specifically female youth from the sub-Sahara Africa, Phillips (2014) indicates that, in addition to procedural distinction over terms and language there is a lack of personalisation of the human side of asylum seekers, refugees and migrants seeking to enter Europe by sea. It is very difficult to find individual stories behind the hyperactive media headlines claiming thousands more people are potentially on their way to asphyxiate Europe mainly departing from Libya. It is only through individual stories and nuanced accounts of why people leave their homes and their mixed motivations for departing, that we will better understand the factors driving mobility along this route which in turn can shape policy imperatives.

\section{Conclusion}

Evidently female African youth migration to Europe is becoming a huge tragic concern both to Africa and to the receiving nations. As the most populous country in Africa, Nigeria must collaborate with African Union to initiate a 
leading role in addressing youth-related concerns in its domain. Insecurity, unemployment, poverty, and unenviable living conditions were highlighted in literature and earlier research interviews. The efforts of Nigerian leadership in conjunction with $\mathrm{AU}$ and IOM to-manage issues of youth emigration and internally displaced persons, IDPs, are commendable at least for being a timely intervention. It is not, however, an effective or appropriate long-term solution to the serious social concern that youth emigration represents. Detailed systematic enquiries and investigative media reportage on African migration from the lenses of the sending and receiving societies are past overdue. Global media attentions and empirical academic researches on Africa-Europe migration must adopt new trajectory, a perspective that reflects on how policies and praxis have ignored the demographic details of the trend, thereby leaving the most vulnerable categories of the phenomenon (female youth and children) out of the discursive equation. Evidence-base and verifiable data reports on the short and long run implications of African youth emigration might help to jolt lumber-stricken leaders in the continent to the realities not just of the tragedies characterized in the flow of female youth cross-border movement, but the future socio-economic implications with respect to sustainable development in the continent. Female youth and children are yet more susceptible to the vagaries of $21^{\text {st }}$ century transnational border interactions as most policies on international migration are adult-specific. This accounts for why the presence of IOM and creation of National Agency for the Prohibition of Trafficking in Persons (NAPTIP) has not succeeded in reducing or eradicating youth emigration from Nigeria, and by extension the continent. We insist that more researches be carried out to understand the motive and compelling circumstance informing the $21^{\text {st }}$ century female youth transnational border-crossing as a way of proffering solution to the malaise as opposed to labeling and criminalization particularly of young female migrants at the borders of industrialized world. European media misrepresentations have resulted in negative public opinions, and subsequent detrimental restrictions and oppressive practices against these migrants both at EU borders and in the host societies. Depending on the aim of the strategists here, this approach has proven counterproductive at reducing the flow and tragedies associated with Africa-Europe youth migration, and more specifically female youth irregular cross-border movement.

\section{Conflicts of Interest}

The authors declare no conflicts of interest regarding the publication of this paper.

\section{References}

Abuzayd, K. (2016). Independent International Commission of Inquiry on the Syrian Arab Republic, Mandated by the UN Human Rights Council; Former UN Under Secretary-General; Former Commissioner-General, UNRWA. https://www.ohchr.org/EN/HRBodies/HRC/IICISyria/Pages/Biographies.aspx 
Adepoju, A. (2008a). Current African Issues: Migration in Sub-Saharan Africa. Sweden: Nordiska Africa Institutet.

Adepoju, A. (Ed.). (2008b). Perspectives on International Migration and National Development in Sub-Saharan Africa. In A. Adepoju, T. Van Naerssen, \& A. Zoomers (Eds.), International Migration and National Development in Sub-Saharan Africa: Viewpoints and Policy Initiatives in the Countries of Origin. The Netherlands: Brill.: Afrika Studiecentrum Series.

Akanle, O. (2013). Kinship Networks and International Migration in Nigeria. Newcastle, UK: Cambridge Scholars Publishing.

Baxter, J. (2008). Dust from Our Eyes: An Unblinkered Look at Africa. Hamilton: Wolsak and Wynn Publishers.

Belsey, C. (2002) Poststructuralism: A Very Short Introduction. New York: Oxford University Press. https://doi.org/10.1093/actrade/9780192801807.001.0001

Berriane, M., \& de Haas, H. (2012). Introduction: New Questions for Innovative Migration Research. In M. Berriane, \& H. de Haas (Eds.), African Migrations Research: Innovative Methods and Methodologies. New Jersey: Africa World Press.

Brachet, J. (2012). From One Stage to the Next: Transit and Transport in (Trans) Saharan Migrations. In M. Berriane, \& H. de Haas (Eds.), African Migrations Research: Innovative Methods and Methodologies. New Jersey: Africa World Press.

Brown, W. (1993). Wounded Attachments. Political Theory, 21, 390-410. https://doi.org/10.1177/0090591793021003003

Browne, S. A. (2007). Trusted Travelers: The Identity-Industrial Complex, Race and Canada's Permanent Resident Card. Unpublished Doctor of Philosophy Thesis, Department of Sociology and Equity Studies in Education, OISE, University of Toronto.

Castles, S., \& Miller, M. J. (2009). The Age of Migration: International Population Movements in the Modern World. New York: Guilford Publications Inc.

Chomsky, N. (2006). Failed States: The Abuse of Power and Assault on Democracy. New York: Henry Holt Books.

Chua, A. (2003). World on Fire: How Exporting Free-Market Democracy Breeds Ethnic Hatred \& Global Instability. New York: Doubleday Publishing.

Davies, B. (2006). Subjectification: The Relevance of Butler's Analysis for Education. British Journal of Sociology of Education, 27, 425-438. https://doi.org/10.1080/01425690600802907

de Haas, H. (2006). Perspectives on International Migration and National Development in Sub-Saharan Africa. In A. Adepoju, T. Van Naerssen, \& A. Zoomers (Eds.), International Migration and National Development in Sub-Saharan Africa: Viewpoints and Policy Initiatives in the Countries of Origin (pp. 21-48). Leiden: Brill Publishers.

de Haas, H. (2008). The Myth of Invasion: The Inconvenient Realities of African Migration to Europe Globalisation and Migration: New Issues, New Politics? Third World Quarterly, 29, 1305-1322. https://doi.org/10.1080/01436590802386435 https://www.jstor.org/stable/20455111?seq=1\#page_scan_tab_contents

Deaux, K. (2006). Setting the Stage: Policies, Demography, and Social Representations. In K. Deaux (Ed.), To Be an Immigrant. New York: Russell Sage Foundation.

Falola, T., \& Afolabi, N. (2007). Introduction: Migration Fantasies, Nightmarish Realities. In T. Falola, \& N. Afolabi (Eds.), The Human Cost of African Migrations. New York: Routledge.

Fanon, F. (1952). Black Skin, White Masks. New York: Grove Press. 
Immigration and Refugee Board of Canada (2010). Interpreters Training Manual (p. 7).

Kapur, R. (2005). Erotic Justice: Law and the New Politics of Post Colonialism. London: Glass House Press.

Ki-moon, B. (2009). Migration through the Eyes of Young People Panel on the Occasion of International Migrants' Day. New York: United Nations Institute for Training and Research (UNITAR), United Nations Headquarters.

Kneli, Y. (2013). Israeli Ethiopian Birth Control to Be Examined. BBC News.

Li, P. (2003). Destination Canada: Immigration Debates and Issues. Toronto: Oxford University Press.

Lowry, M., \& Nyers, P. (2003). Global Movements for Refugee and Migrant Rights. Refuge, 21, 66-72.

Memmi, A. (2006). Decolonization and the Decolonized(Robert, B. Trans.). Minneapolis, MN: University of Minnesota Press.

Moses, J. (2006). Some Historical Perspectives.

Nesher, T. (2015). Israel Admits Ethiopian Women Were Given Birth Control Shots (Haaretz Digital Edition).

Nwalutu, M. O. (2015). 21st Century Youth Migration versus Border Restrictions: A Critique. Lambert Academic Publishing.

Nwalutu, M. O. (2016). From Africa to Europe, Youth and Transnational Migration: Examining the Lived Experiences of Nigerian Migrant Youth in Malta. $\mathrm{PhD}$ Thesis, Toronto: ProQuest/Uof T Library Repository.

https://tspace.library.utoronto.ca/browse?type=title\&sort_by=1\&order=ASC\&rpp=20\& etal=-1\&starts_with=from+Africa+to+Europe

Phillips, M. (2014). Guest Post: The Effect of Negative Labeling-Why Are We Still Talking about "Migrants"? Migrants at Sea.

http://migrantsatsea.org/2014/07/01/guest-post-the-effect-of-negative-labelling-why-ar e-we-still-talking-about-migrants/

Pisani, M. (2011). There's an Elephant in the Room and She's "Rejected" and Black: Observations on Rejected Female Asylum Seekers from Sub-Saharan Africa in Malta. Open Citizenship, 2, 24-51.

Pisani, M. (2012). Lifelong Learning and Inclusion: The "Citizenship Assumption" and the Exclusion of 8 Million Bodies. In 44th EUCEN November Conference "Border-Crossing as a Viable Choice: Collaboration, Dialogue and Access to Higher Education.

Rosenberg, S. (2004). An Introduction to Feminist Poststructural Theorizing. In N. Mandell (Ed.), Feminist Issues: Race, Class and Sexuality (4th Ed., pp. 35-57). Toronto: Pearson/Prentice Hall.

Sassen, S. (1988). The Mobility of Labor and Capital: A Study in International Investment and Labor Flow. Cambridge: University Press. https://doi.org/10.1017/CBO9780511598296

Sassen, S. (2003). Global Cities and Survival Circuits. In B. Ehrenreich, \& A. R. Hochschild (Eds.), Global Woman: Nannies, Maids and Sex Workers in the New Economy. London: Granta Books.

Sharma, N. (2005). Anti-Trafficking Rhetoric and the Making of a Global Apartheid. NWSA Journal, 3, 88-111. https://doi.org/10.2979/NWS.2005.17.3.88 http://muse.jhu.edu/journals/ff/summary/v017/17.3sharma.html

Siebert, F. S., Peterson, T., \& Schramm, W. (1963). Four Theories of the Press: The Au- 
thoritarian, Libertarian, Social Responsibility, and Soviet Communist Concepts of What the Press Should Be and Do. Champaign, IL: University of Illinois Press.

https://doi.org/10.5406/j.ctv1nhr0v

Simms, A. (2009). Ecological Debt: Global Warming \& the Wealth of Nations. New York: Pluto Press.

Sunderland, J. (2012). Hidden Emergency: Migrants Death in the Mediterranean. Human Rights in Europe. New York: Human Rights Watch.

http://www.hrw.org/sites/default/files/related_material/2012_EU_Hidden\%20Emergen cy.pdf

Toasije, A. (2009). The Africanity of Spain: Identity and Problemitization. Journal of Black Studies, 39, 348-355. http://jbs.sagepub.com/content/39/3/348.full.pdf+html https://doi.org/10.1177/0021934706297563

Wong, S. (2009). Migration through the Eyes of Young People Panel on the Occasion of International Migrants' Day. New York: United Nations Institute for Training and Research (UNITAR), United Nations Headquarters. 